\section{'AC Harrow Crisp' Pear}

\author{
David M. Hunter ${ }^{1}$ \\ Agriculture and Agri-Food Canada, Southern Crop Protection and Food \\ Research Centre, Vineland Station, ON, LOR 2EO, Canada
}

Frank Kappel and Harvey A. Quamme

Agriculture and Agri-Food Canada, Pacific Agri-Food Research Centre, Summerland, BC, VOH 1Z0, Canada

W. Gordon Bonn'

Agriculture and Agri-Food Canada, Greenhouse and Processing CropsResearch Centre, Harrow, ON, NOR 1GO, Canada

Additional index words. Pyrus communis, fire blight, Erwinia amylovora, resistance

'AC Harrow Crisp' pear (Pyrus communis L.) is a very attractive midseason pear for the fresh market. The tree is moderately productive with no evidence of biennial bearing habit, and has excellent resistance to fire blight [Erwinia amylovora (Burr.) Winslow et al.]. This new cultivar, developed by Agriculture and Agri-Food Canada at Harrow, Ont., Canada, is recommended by the Ontario Tender Fruit Producers' Marketing Board for trial planting in Ontario. It is being protected under Canadian Plant Breeders Rights legislation (application number 002184).

\section{Origin}

'AC Harrow Crisp' pear originated from a cross of 'Bartlett' $x$ US56112-146 made in 1972 by H.A. Quamme at Harrow (Fig. 1). 'AC Harrow Crisp' was selected in 1979 by H.A. Quamme and propagated in 1980 for second test. Trees were propagated in cooperation with the Western Ontario Fruit Testing Association (now the Ontario Fruit Testing Association), and placed in regional trials with cooperating growers beginning in 1984 under the designation HW610. 'AC Harrow Crisp' was included in regional evaluation orchards planted in Ontario in 1992. It was also included in a 1999 planting of fire blight-resistant cultivars and selections for evaluation of commercial processing capabilities. 'AC Harrow Crisp' has been tested in Canada, the United States, and in Europe.

Received for publication 12 Dec. 2000. Accepted for publication 9 May 2001. We thank P. Pinsonneault, P.R. Timmins, M.F. Gadsby, and D.B. Jessop for excellent technical assistance. We appreciate the assistance of the Western Ontario Fruit Testing Association and its grower-members in field performance evaluations.

${ }^{1}$ To whom reprint requests should be addressed. Current address: Univ. of Guelph, Dept. of Plant Agriculture, 4890 Victoria Ave. N., P.O. Box 7000, Vineland Station ON, Canada. E-mail: dhunter@uoguelph.ca

${ }^{2}$ Present address: BIOBONNEX Inc., 1035 Beals Street, Windsor, ON, N9E 4B7, Canada

\section{Description and Performance:}

\section{Tree characteristics}

Tree habitand productivity. The tree of 'AC Harrow Crisp' is medium in size, conical and upright, annually productive, and winter hardy. In 1994 at Harrow, the original seedling tree and trees grown on Bartlett seedling rootstock produced a full crop following winter minimum temperatures as low as $-29^{\circ} \mathrm{C}$. When propagated on Bartlett seedling rootstock, precocity of 'AC Harrow Crisp' is similar to that of 'Bartlett', with bearing initiated within a 4-year period after planting. Annual yields have been greater than those of 'Bartlett', especially in areas where fire blight has adversely affected the productivity of 'Bartlett'. In an evaluation orchard planted in 1982 at Harrow, 'ACHarrow Crisp' produced commercially acceptable crops until the orchard was removed in Fall 2000 (data not presented), while all 'Bartlett' trees
Fig. 1. Pedigree of ‘AC Harrow Crisp’ pear. Summerland, B.C., Canada. ${ }^{2}$ had been removed by 1990 because of extensive fire blight damage. 'AC Harrow Crisp' out-yielded 'Anjou' and 'Bosc' in the first 5 years of an orchard planted at Summerland, B.C. (Table 1).

Shoot. The bark on the sun-exposed side of dormant shoots is brown (RHS 165A, Royal Horticultural Society, 1966). Mean internode length of 'AC Harrow Crisp' was similar to 'Bartlett' and 'Harrow Sweet', but shorter than 'Harvest Queen' and 'Bosc' (Table 2).

Leaves. The leaves are elliptic. The shape of the base of the leaf blade is obtuse. The shape of the upper part of the leaf blade is right-angled, with a pointed acuminate tip. There is little curvature of the midrib. Leaf serrations are small and shallow but distinct. The angle between the petiole and the shoot is $<30 \%$, the petiole is medium in length, and stipules are absent. The attitude of the leaf in relation to the shoot is upwards. Actively growing shoot tips are reddish-green with light pubescence.

Fire blight resistance. As with other introductions from the Harrow pear breeding program (Hunter et al., 1992, 2002; Quamme and Spearman, 1983], 'AC Harrow Crisp' has excellent resistance to fire blight, similar to or greater than that of 'Kieffer', which is used as the standard for selection (Hunter, 1993). Using natural fire blight infection scores (van der Zwet et al., 1970), 'AC Harrow Crisp' had a resistance rating much greater than 'Bartlett' (Table 3 ). When actively growing shoot tips were inoculated with a mixture of six virulent strains of E. amylovora, the length of the lesion that developed extended to $\approx 12 \%$ of current season's growth, similar to 'Harrow Sweet' and 'Kieffer', but much less than lesion development in 'Bartlett' (Table 3).

Bloom and pollination. At Harrow, the time of full bloom of 'AC Harrow Crisp' is

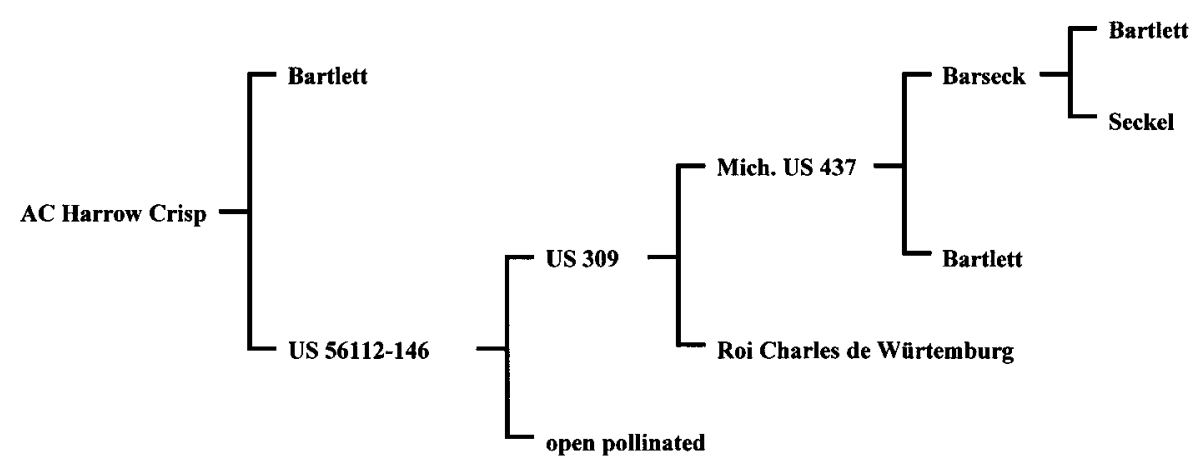

Table 1. Annual fruit yields of 'AC Harrow Crisp', 'Anjou', 'Bosc', and 'Harrow Sweet' at

\begin{tabular}{|c|c|c|c|c|c|c|}
\hline \multirow[b]{2}{*}{ Cultivar } & \multicolumn{5}{|c|}{ Annual yield (kg/tree) } & \multirow{2}{*}{$\begin{array}{c}\text { Cumulative yield } \\
(\mathrm{kg} / \text { tree })\end{array}$} \\
\hline & 1989 & 1990 & 1991 & 1992 & 1993 & \\
\hline AC Harrow Crisp & $7.6 \mathrm{a}^{\mathrm{y}}$ & $4.3 \mathrm{ab}$ & $18.7 \mathrm{a}$ & $12.5 \mathrm{a}$ & $21.4 \mathrm{ab}$ & 64.5 \\
\hline Anjou & $1.2 \mathrm{c}$ & $2.4 \mathrm{~b}$ & $9.4 \mathrm{a}$ & $3.9 \mathrm{~b}$ & $27.8 \mathrm{ab}$ & 44.7 \\
\hline Bosc & $3.2 \mathrm{~b}$ & $4.5 \mathrm{ab}$ & $16.5 \mathrm{a}$ & $13.6 \mathrm{a}$ & $20.1 \mathrm{~b}$ & 57.9 \\
\hline Harrow Sweet & $7.7 \mathrm{a}$ & $8.1 \mathrm{a}$ & $16.4 \mathrm{a}$ & $5.4 \mathrm{~b}$ & $32.7 \mathrm{a}$ & 70.3 \\
\hline
\end{tabular}

${ }^{2}$ Orchard was planted in 1987 with five single tree replicates in a completely randomized design. ${ }^{y}$ Means separation within columns by Waller-Duncan $\mathrm{K}$ ratio $t$ test, $P=0.05$. Means within columns followed by the same letter are not significantly different. 
Table 2. Mean internode length $(\mathrm{cm} \pm \mathrm{SE})$ as determined on five successive internodes from the mid-portion of 1-year-old shoots ${ }^{2}$

\begin{tabular}{lcc}
\hline \hline Cultivar & $\begin{array}{c}\text { Internode } \\
\text { length }\end{array}$ & $\begin{array}{c}\text { No. of } \\
\text { shoots }\end{array}$ \\
\hline AC Harrow Crisp & $3.1 \pm 0.1$ & 19 \\
Bartlett & $3.3 \pm 0.1$ & 13 \\
Harrow Sweet & $3.1 \pm 0.1$ & 15 \\
Harvest Queen & $3.7 \pm 0.2$ & 17 \\
Bosc & $4.4 \pm 0.1$ & 14 \\
\hline
\end{tabular}

${ }^{2}$ Shoots harvested in Feb. 1996 from mature trees ( $>10$ years old) grown on 'Bartlett' seedling rootstock at Harrow, Ont., Canada.

similar to that of 'Bartlett'. First bloom, however, is $2 \mathrm{~d}$ later than 'Bartlett'. Flower clusters typically contain seven flowers, occasionally six or eight, rarely five or nine. Petals are white, almost as long as broad, and just touch with no overlap. The pink to red anthers are large in size, and are level with or slightly above the stigma. 'AC Harrow Crisp' tends to be a poor pollinizer.

In controlled pollination tests, fruit set was used to determine pollen compatibility when pollen from a known source was applied to stigmatic surfaces immediately after emasculation of the flower. Because emasculated pear flowers are even less attractive to bees and other pollinating insects than nonemasculated flowers, bagging was not considered necessary. 'AC Harrow Crisp' will not consistently pollinate 'Bartlett', 'Bosc', or 'Anjou', especially when spring weather is warm and humid; however, under the cooler conditions experienced in Spring 2000, 'AC Harrow Crisp' pollinated 'Bartlett', 'Bosc', 'Anjou', 'Flemish Beauty', and 'AC Harrow Gold', but these cultivars did not adequately pollinate 'AC Harrow Crisp'. Also in 2000, pollination of emasculated flowers of 'AC Harrow Crisp' with pollen of 'AC Harrow Crisp' resulted in adequate fruit set for commercial production. Seed set in 'AC Harrow Crisp' tends to be low, and largesized fruits can develop with few or no viable seeds.

\section{Fruit characteristics}

Size, shape, and color. Fruits are slightly larger than 'Bartlett' (Table 4). Fruit shape is symmetrical, pyriform, and concave to almost straight in profile. Using International Board for Plant Genetic Resources descriptors (Thibault et al., 1983), the predominant fruit shape has been described as $5.2(\approx 50 \%$ of individual fruits), while other individual fruits have been described as $5.4(\approx 25 \%)$ or $7.2(\approx 20 \%)$. The calyx is persistent at harvest, with short to medium length sepals that are convergent to upright. The calyx basin is medium depth and narrow to medium in width, and the margin is even to slightly ribbed. Following ripening at $\approx 20^{\circ} \mathrm{C}$, the skin has a very attractive golden yellow ground color (RHS $11 \mathrm{~A}$ or $11 \mathrm{~B}$ ) with a red blush on the sun-exposed fruit surface. The skin is very smooth and there is little or no russeting of the fruit. The flesh is white to cream-white in

Table 3. Ratings of natural and induced fire blight infections of 'AC Harrow Crisp' in comparison to 'Bartlett', 'Harrow Sweet', and 'Kieffer'.

\begin{tabular}{lcccc}
\hline \hline & AC Harrow Crisp & Bartlett & Harrow Sweet & Kieffer \\
\hline Rating & \multicolumn{4}{c}{ Natural infections $^{2}$} \\
Years evaluated & $9.5 \pm 0.2$ & $4.2 \pm 0.4$ & $9.2 \pm 0.2$ & $9.3 \pm 0.1$ \\
& 13 & 18 & 17 & 15 \\
Lesion (\% shoot length) & $11.8 \pm 3.0$ & Induced infections & & \\
Years evaluated & 11 & $62.8 \pm 4.2$ & $14.1 \pm 2.5$ & $23.1 \pm 1.6$ \\
\hline
\end{tabular}

${ }^{2}$ Natural fire blight infections, rated on a scale of 1 (tree dead) to 10 (no blight), are means \pm SE of 13 to 18 years at Harrow, Ont., Canada. The rating system was modified from van der Zwet et al. (1970) by assigning values of $10=$ no visible blight and $9=<3 \%$ infection. For 'AC Harrow Crisp' and 'Harrow Sweet', ratings were made on the own-rooted seedling tree. For 'Bartlett' and 'Kieffer', ratings were made on trees grown on 'Bartlett' seedling rootstock in a nearby (within $200 \mathrm{~m}$ ) cultivar evaluation orchard. In both the seedling orchard and the cultivar evaluation orchard, susceptible trees had severe fire blight infections each year. y Induced infections were rated in late July, $\approx 5$ weeks after inoculating 10-20 actively growing shoots with $20 \mu \mathrm{L}$ of a cocktail of six virulent strains of Erwinia amylovora $\left(10^{8} \mathrm{cfu} / \mathrm{mL}\right)$. Values indicate lesion length expressed as a percentage of total shoot length. Data are means \pm SE of 11 to 22 years.

color, very fine in texture, grit-free, and remains firm even when fully ripe. Fruits have a mild sweet flavor and relatively little juice.

Maturity. At Harrow, Ont., Canada, the fruits of 'AC Harrow Crisp' mature at the end of August or early September, just after 'Bartlett' (Table 4), and can be harvested over a 2-week period. Early picked fruits can be stored in common cold storage $\left(1\right.$ to $2{ }^{\circ} \mathrm{C}$ ) for $\approx 2$ months, but storage life is reduced with later picking. Core breakdown can be a problem with overripe fruits.

Table 4. Harvest dates at Harrow, Ont., Canada, and fresh fruit evaluations for 'Bartlett', 'AC Harrow Crisp', and 'Harrow Sweet'.

\begin{tabular}{|c|c|c|c|}
\hline & Bartlett & $\begin{array}{c}\mathrm{AC} \\
\text { Harrow } \\
\text { Crisp }\end{array}$ & $\begin{array}{c}\text { Harrow } \\
\text { Sweet }\end{array}$ \\
\hline Years evaluated & 20 & 17 & 18 \\
\hline \multicolumn{4}{|l|}{ Harvest dates } \\
\hline Average & 28 Aug. & 3 Sept. & 18 Sept. \\
\hline Earliest & 18 Aug. & 22 Aug. & 29 Aug. \\
\hline Latest & 9 Sept. & 27 Sept. & 8 Oct. \\
\hline \multicolumn{4}{|l|}{ Size $(\mathrm{mm})$} \\
\hline Length & $81.4 \mathrm{a}^{\mathrm{z}}$ & $84.4 \mathrm{a}$ & $84.6 \mathrm{a}$ \\
\hline Diameter & $63.4 \mathrm{a}$ & $65.1 \mathrm{a}$ & $63.5 \mathrm{a}$ \\
\hline \multicolumn{4}{|l|}{ Ratings $^{\mathrm{y}}$} \\
\hline Appearance ${ }^{x}$ & $7.7 \mathrm{~b}$ & $8.6 \mathrm{a}$ & $7.4 \mathrm{~b}$ \\
\hline Flavor $^{\mathrm{x}}$ & $8.0 \mathrm{a}$ & $7.4 \mathrm{~b}$ & $7.8 \mathrm{ab}$ \\
\hline Texture $^{\mathrm{x}}$ & $7.9 \mathrm{a}$ & $7.4 \mathrm{ab}$ & $7.1 \mathrm{~b}$ \\
\hline Weighted score ${ }^{w}$ & $81.3 \mathrm{a}$ & $79.4 \mathrm{ab}$ & $77.1 \mathrm{~b}$ \\
\hline Grit $^{v}$ & $3.9 \mathrm{a}$ & $4.2 \mathrm{a}$ & $3.1 \mathrm{~b}$ \\
\hline Juice $^{\mathrm{u}}$ & $3.9 \mathrm{a}$ & $3.1 \mathrm{~b}$ & $4.2 \mathrm{a}$ \\
\hline Core $^{t}$ & $3.2 \mathrm{~b}$ & $3.0 \mathrm{~b}$ & $3.8 \mathrm{a}$ \\
\hline
\end{tabular}

${ }^{2}$ Means separation within rows by Duncan's new multiple range test, $P=0.05$. Means within rows followed by the same letter are not significantly different

${ }^{y}$ Ratings reported are based on evaluations of fruits ripened immediately after harvest.

${ }^{x}$ Appearance, flavor and texture ratings [on a scale of 1 (least desirable) to 9 (most desirable)] were determined each year by two to four trained panelists.

${ }^{\text {w }}$ Weighted score $=(3 \times$ appearance $)+(5 \times$ flavor $)+$ $(2 \times$ texture $)$.

'Grit rating is on a scale of 1 (undesirable, i.e. large and/or many grit cells) to 5 (desirable, i.e., very small and/or few or no grit cells).

"Juiciness rating is on a scale of 1 (dry) to 5 (very juicy).

'Core size rating is on a scale of 1 (small) to 5 (large).
Quality. At Harrow, fruits were harvested each year at the normal fresh market maturity for commercial harvest $(5-7 \mathrm{~kg}$ pressure). Following ripening at $\approx 20^{\circ} \mathrm{C}$ until 'eating ripe', a sample of 5-10 fruits, selected at random, was evaluated for appearance, flavor, texture, number and size of grit (stone cells) in the flesh, juiciness, and core size relative to fruit size. Evaluations were made on fruits ripened immediately after harvest. At Harrow, trained panelists rated the appearance of ripened fruits of 'AC Harrow Crisp' as excellent, and significantly better than 'Bartlett' and 'Harrow Sweet'. Fresh fruit quality of 'AC Harrow Crisp', as indicated by the weighted score, was intermediate between, but not statistically different from, 'Bartlett' and 'Harrow Sweet' (Table 4). There were no significant differences between fruits ripened immediately after harvest and fruits ripened after 4 weeks in a

Table 5.Ratings of pear halves ${ }^{z}$ and pear purée ${ }^{y}$ processed from ripened fruits of 'AC Harrow Crisp' in comparison with 'Bartlett' and 'Harrow Sweet'.

\begin{tabular}{lccc}
\hline \hline & $\begin{array}{c}\text { AC Harrow } \\
\text { Crisp }\end{array}$ & Bartlett & $\begin{array}{c}\text { Harrow } \\
\text { Sweet }\end{array}$ \\
\hline Halves & $3.8 \mathrm{a}^{\mathrm{x}}$ & $3.9 \mathrm{a}$ & $3.4 \mathrm{~b}$ \\
Puree & $3.6 \mathrm{~b}$ & $4.0 \mathrm{a}$ & $3.3 \mathrm{~b}$ \\
\hline
\end{tabular}

${ }^{2}$ Determined with masked identity taste panels involving four trained panelists. Fruits were processed in syrup containing $15 \%(\mathrm{w} / \mathrm{v})$ sugar. Processing rating for pear halves is the average of ratings for flavor, texture and appearance on a scale of 1 (least desirable) to 5 (most desirable). Samples, including a masked identity 'Bartlett' sample, were compared to a known 'Bartlett' sample. Data presented are means of 5 years.

'Determined with masked identity taste panels involving four trained panelists. Fruits were processed with no additional sugar. Processing rating for purée is the average of ratings for viscosity, color, and flavor on a scale of 1 (least desirable) to 5 (most desirable). Samples, including a masked identity 'Bartlett' sample, were compared to a known 'Bartlett' sample. Data presented are means of 5 years.

'Means separation within rows by Duncan's new multiple range test, $P=0.05$. Means within rows followed by the same letter are not significantly different. 
common cold storage at $\approx 2{ }^{\circ} \mathrm{C}$ (data not presented).

Processing evaluations. When ripened fruits are processed as pear halves, 'AC Harrow Crisp' remains intact, with virtually no breakdown, and there is no discoloration of the fruit or syrup. 'AC Harrow Crisp' rates almost as highly as 'Bartlett', and significantly better than 'Harrow Sweet' (Table 5). When processed as pear purée, 'AC Harrow Crisp' is rated better than 'Harrow Sweet' but not as high as 'Bartlett'. While the processed product from small scale trials has been rated good, the quality may not be sufficiently high for 'AC Harrow Crisp' to have commercial acceptability for processing as halves or puree in the current market. The commercial processing potential of this new cultivar will be further evaluated when large scale plantings established in 1999 come into production.

\section{Availability}

'AC Harrow Crisp' was tested at the Canadian Centre for Plant Health, Saanichton, B.C., using woody-host and herbaceous-host biological indicators, and by serological and molecular methods, and found to be free of all known viruses, virus-like agents, viroids, and phytoplasmas. Virus-tested trees have been planted in the Canadian Clonal Gene Bank at Harrow. 'AC Harrow Crisp' is protected under Canadian Plant Breeders Rights legislation, and is being protected in the European Union. Commercialization rights have been granted to Inter-Plant Patent Marketing, R.R. 2, Niagaraon-the-Lake ON, Canada LOS 1J0 (for North America) and to Star Fruits, Route d'Orange 84860 Caderousse, France (for the European Union). Information on tree availability and inquiries regarding the licensing of commercial propagation may be addressed to these agents.

\section{Literature Cited}

Hunter, D.M. 1993. Pear breeding for the $21^{\text {st }}$ century-Program and progress at Harrow. Acta Hort. 338:377-383.

Hunter, D.M., P. Pinsonneault, F. Kappel, H.A. Quamme, W.G. Bonn, and R.E.C. Layne. 1992. 'Harrow Sweet' pear. HortScience 27:1331-1334.

Hunter, D.M., F. Kappel, H.A. Quamme, and W.G. Bonn. 2002. 'AC Harrow Gold' pear. HortScience 37:224-226.

Quamme, H.A. and G.A. Spearman. 1983. 'Harvest Queen' and 'Harrow Delight' pear. HortScience 18:770-772.

Royal Horticultural Society. 1966. Royal Horticultural Society Colour Chart. Royal Hort. Soc., London.

Thibault, B., R. Watkins and R.A. Smith (eds.). 1983. Descriptor list for pears (Pyrus). Intl. Board Plant Genet. Resources. IBPGR Secretariat, Rome.

van der Zwet, T., W.A. Oitto and H.J. Brooks. 1970. Scoring system for rating the severity of fire blight in pear. Plant Dis. Rpt. 54:835-839. 